\title{
Edward Flatau (1868-1932) and his eponym
}

\author{
Yasemin Kaya • Gokhan Akkoyunlu • Levent Sarikcioglu
}

Received: 9 September 2014 / Accepted: 24 September 2014 / Published online: 2 October 2014

(C) Springer-Verlag Berlin Heidelberg 2014

Edward Flatau was one of the famous Polish neurologists. He was known as a founder and the father of neurology in Poland. In Polish neurological bibliography, he was called the Master of Neurology [8].

\section{His life}

Edward Flatau was born on December 27, 1869 in Płock (a city in central Poland) at a time when Poland was absent from official European maps since the territory of Poland had been divided between three neighboring countries: Germany, Russia, and Austria [8]. Since there were no official Polish schools or universities at those years, many Polish scientists had to fulfill their education abroad [8]. Edward Flatau was not the exception among many scientists. In 1886, he went to the University of Moscow for his medical education [6]. In Moscow, he was greatly influenced by the Russian psychiatrist Sergei Sergeievich Korsakoff (1854-1900) and the neurologist and psychiatrist Alexis Jakovlevich Kozhevnikof (18361902). Flatau became a medical doctor in 1892 with the distinction of cum eximia lauda (with particular honor) and

\footnotetext{
Y. Kaya $\cdot$ L. Sarikcioglu $(\bowtie)$

Department of Anatomy, Faculty of Medicine, Akdeniz University, 07070 Antalya, Turkey

e-mail: levent@akdeniz.edu.tr

L. Sarikcioglu

e-mail: sarikcioglul@gmail.com

Y. Kaya

e-mail: ybehramkaya@akdeniz.edu.tr

G. Akkoyunlu

Department of Histology and Embryology, Faculty of Medicine, Akdeniz University, 07070 Antalya, Turkey

e-mail: gokhan_akkoyunlu@hotmail.com
}

later continued his medical education and research activities, especially in neuroanatomy, in Berlin under the supervision of Emanuel Mendel (1839-1907), Wilhelm von Waldeyer-Hartz (1836-1921), Karl August Eugen Alfred Goldscheider (1858-1935), and Ernst Viktor von Leyden (1832-1910) [6]. After completing his studies in Berlin (1893-1896), he returned to Poland and was appointed as the Head of the Department of Neurology at the Jewish Hospital in Czyste District of Warsaw (Warsaw's Starozakonnych na Czystem Hospital) [6, 9].

He contributed to re-establish Polish neuroscience during and after Russian occupation and attempted to teach many Polish neurologists [8]. In 1911, he established a neurological laboratory in the Warsaw Psychologic Society. In 1913, he became the first head of the Department of Neurobiology of Warsaw Scientific Society (Warszawskie Towarzystwo Naukowe). In 1919, he was appointed as the head of the Nencki Institute of Experimental Biology which was then part of the Warsaw Scientific Society [1]. Together with Samuel Vulfovitsj Goldflam (1852-1932), he established the Pathology Scientific Institute and the medical periodical "Warszawskie Czasopismo Naukowe" [1].

He died in 1932, the same year with two other great neurologists, Joseph Jules François Félix Babinski (18571932) and Samuel Vulfovitsj Goldflam (1852-1932). All of them died in a period of 5 months. In his last years, he had suffered from a brain tumor.

\section{His achievements}

Our knowledge on spinal cord anatomy dates back. However, the history of the detailed anatomy of the spinal cord is relatively short compared with that of other parts of the brain [7]. Our knowledge on the organization, location, and direction of tracts of the spinal cord were based on the studies of Domenico Mistichelli (1675-1715), Karl Friedrich Burdach 
(1776-1847), Ludwig Türck (1810-1868), Jacob Augustus Lockhart Clarke (1817-1880), Charles-Édouard BrownSéquard (1817-1894), Friedrich Goll (1829-1903), Henry Charlton Bastian (1837-1915), Sir William Richard Gowers (1845-1915), Paul Emil Flechsig (1847-1929), Constantin von Monokow (1853-1930), and many others. Traumas or experimental lesions of the spinal cord had also given valuable knowledge. Charles-Édouard Brown-Séquard described hemisection of the spinal cord. Henry Charlton Bastian (1837-1915) demonstrated that in complete transverse lesions of the spinal cord, reflexes below the level of the lesion are lost and muscle tone is abolished [7].

Dr. Flatau also described detailed anatomy of the spinal cord tracts. In 1894, at the age of 26, Edward Flatau published a monograph entitled Atlas des menschlichen Gehirns und des Faserverlaufes (Atlas of the human brain and the course of the nerve fibers) which was originally published in German [2] and next translated into English, French, Russian, and Polish $[6,8,9]$. This atlas was based on his own photographs of the brain and spinal cord obtained from the Neuropsychiatric Institute of Emanuel Mendel (1839-1907) [6, 8]. He also provided schematic chromolithograph in color which demonstrated the laminar arrangement of the spinal tracts [6].

Flatau became a member of Waldeyer's Anatomical Institute two years after Waldeyer had coined the word "neuron" (spelled neurone in British English). Waldeyer (1836-1921), Dr. Flatau, and many well-known scientists became supporters of the neuron theory [6]. Using the Nissl method, Dr. Flatau performed many experimental studies to test the neuron theory and observed subsequent secondary changes from the severance of the oculomotor nerve [6]. Using Golgi and Marchi methods, he performed experimental works on dogs, rabbits, and rodents to study secondary degeneration after limb amputation and to observe the loss of function following spinal cord injury [9]. In addition to his studies on the functional anatomy of the spinal cord, he reported an original map of the dermatomes and described nuclei and course of the fifth, seventh, and eighth cranial nerves [6,9].

Apart from his studies on spinal cord anatomy, Dr. Flatau made important contributions to neurology. In 1911, Dr. Flatau and Wladyslaw Sterling, a neurophysiologist and his pupil, described torsion spasm in children [5]. In the same year, Georg Theodor Ziehen (18621950) and Hermann Oppenheim (1858-1919), independent from each other, also described the same illness. Interestingly, torsion spasm in children is now known as Ziehen-Oppenheim syndrome [1]. Flatau and Sterling examined a couple of Jewish boys in clinic over a 2year period. In both cases, muscle spasm progressed gradually and affected all muscles except those of the face and those required for speech (dysphonia was not found) [6]. In 1912, Flatau also published a monograph on migraine [4]. This monograph was published in the Neurology-Psychiatry Journal and was based on 500 patients he had examined and categorized, and it discussed the association of migraine with epilepsy [6]. In 1927, Flatau, independent from Austrian neurologist Emil Redlich (1866-1930), reported first description of cases with encephalomyelitis epidemica disseminata (now known as Flatau-Redlich disease). Flatau proposed that a virus might be responsible for this illness. Flatau described Schilder disease in detail and introduced its name as encephalitis periaxialis diffusa [1].

He contributed on the creation of three medical periodicals: Neurologia Polska (Polish Neurology), Warszawskie Czasopismo Lekarskie (Warsaw Medical Journal), and the Kwartalnika Klinicznego Szpitala Starozakonnych (Czystem Orthodox Hospital Clinical Quarterly) [6]. Flatau also served as editor-in-chief of Jahresbericht für Neurologie und Psychiatrie from 1897 to 1916 [9].

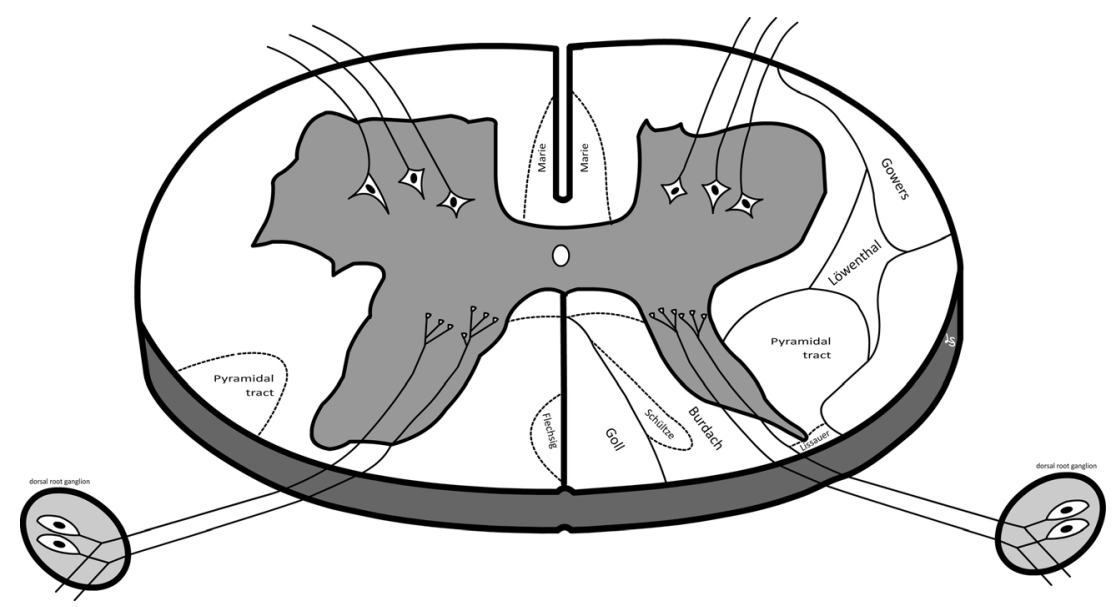

Fig. 1 and cover figure Schematic drawing on the laminar organization of the spinal cord tracts (Flatau's law). Redrawn from original study of Dr. Flatau [2]. Annotations show eponyms of the tracts at the time of the original drawing. Burdach fasciculus cuneatus, Flechsig oval area of
Flechsig, Goll fasciculus gracilis, Gowers fasciculus anterolateralis, Lissauer tract of Lissauer (dorsolateral fasciculus), Löwenthal fasciculus intermediolateralis, Marie fasciculus sulcomarginalis, Schültze comma tract of Schültze 


\section{Flatau's law}

On the basis of numerous clinical spinal cord surgeries, experiments, and subsequent observations, he discovered laminar arrangement of the spinal tracts (Fig. 1 and cover figure) $[9,7]$. His observations on the order of long fibers in the spinal cord became the basis of his doctoral dissertation "Das Gesetz der excentrischen Lagerung der langen Bahnen im Rückenmark" [3]. For this work, he received a Ph.D. degree in medical sciences in Moscow in 1899 [8]. The law is based on the paradigm that longer spinal tracts have a predilection for more peripheral position (in an eccentric position). Flatau described that the "greater the length of the fibers in the spinal cord, the closer they are situated to periphery" [3]. This law still bears his name (Flatau's Law) [9].

Dr. Flatau was an outstanding scientist of his time. He will be remembered by his important contributions on Polish neurology and on our knowledge on the organization, location, and direction of tracts of the spinal cord and some neurological disorders.

Acknowledgments The authors thank Akdeniz University Research Project Unit for their support.
Conflict of interest The authors declare no conflict of interest

\section{References}

1. Enersen OD (2014) http://www.whonamedit.com. Accessed on 1 Sept 2014

2. Flatau E (1894) Atlas des menschlichen Gehirns und des Faserverlaufes. S. Karger, Berlin

3. Flatau E (1897) Das Gesetz der excentrischen Lagerung der langen Bahen im Rückenmark. Zschr Klin Med 33:55-152

4. Flatau E (1912) Die Migräne. Springer, Berlin

5. Flatau E, Sterling W (1911) Progressiver Torsionspasms bei Kindern. Z Gesamte Neurol Psychiatr 7:586-612

6. Gutowski JM (2014) Edward Flatau (1868-1932), Samual Goldflam (1852-1932) and Jozef Babinski (1857-1932): Polish pioneers in neurology. J Med Biogr. doi:10.1177/0967772014525099

7. Naderi S, Ture U, Pait G (2004) History of spinal cord localization. Neurosurg Focus 16(1):1-6

8. Steinborn B, Jozwiak S (2010) History of pediatric neurology in Poland. J Child Neurol 25(2):246-249. doi:10.1177/ 0883073809338411

9. Triarhou LC (2007) Pioneers in neurology. Edward Flatau (18681932). J Neurol 254(5):685-686 